\title{
Syzygium syzygioides (Myrtaceae), a new distributional record for Peninsular India
}

\author{
Shareef S.M. \\ Jawaharlal Nehru Tropical Botanic Garden \& Research Institute, Karimancode PO, Palode, \\ Thiruvananthapuram, Kerala - 695 562, India \\ E-mail: smshariftbgri@gmail.com
}

\begin{abstract}
Syzygium syzygioides (Miq.) Merr. \& L.M.Perry (Myrtaceae) earlier known only from Northeast India to Java and Andaman Islands, is recorded for the first time from Peninsular India. A detailed description, habitat notes and photographs are provided.
\end{abstract}

Keywords: Arippa, Kerala, Taxonomy, Western Ghats.

\section{Introduction}

Syzygium Gaertn., the largest genus in Myrtaceae, comprises about 1200 species distributed from Africa eastwards to the Hawaiian Islands, India and southern China southwards to Australia and New Zealand (Parnell et al., 2007; Govaerts et al., 2020). Seventy two species are so far reported from India, which include eight recently described species from the Western Ghats, two from Andaman Nicobar Islands and one from Northeast India (Viswanathan \& Manikantan, 2008; Shareef et al., 2012, 2014; Sujanapal et al., 2013, 2014; Nayar et al., 2014; Ramana et al., 2014; Narayanan et al., 2014; Murugan \& Arumugam, 2017; Ramasubbu et al., 2018; Sarma et al., 2019). The Western Ghats of Peninsular India shows the highest diversity of the genus in India with 47 species, 20 of which are endemic (Nayar et al., 2014; Govaerts et al., 2020).

During field trips in the foothills of the Western Ghats of Kerala, the author came across an

Received: 30.10.2019; Revised \& Accepted: 30.01 .2020

Published Online: 30.06.2020 interesting specimen from Arippa forests in Kollam district. It is an elegant tree with attractive architecture, glossy foliage and beautiful white flowers, which does not correspond with the other known species from Peninsular India. On critical taxonomic studies with pertinent literature (Miquel, 1855; Kurz, 1877; Duthie, 1878; Parkinson, 1922; Ridley, 1922; Kanjilal et al., 1938; Merrill \& Perry, 1938; Backer \& Bakhuizen Van Den Brink, 1963; Parnell \& Chantaranothai, 2002; Soh \& Parnell, 2015) and type specimens housed at L, it was identified as Syzygium syzygioides (Miq.) Merr. \& L.M.Perry. As the species is not mentioned in any of the floras from the Indian peninsula, it is reported here as a new distributional record for the region and a detailed description with colour photographs is provided for easy identification in the field.

Syzygium syzygioides (Miq.) Merr. \& L.M.Perry, J. Arnold Arbor. 19: 109. 1938. Jambosa syzygioides Miq., Fl. Ned. Ind. 1(1): 431. 1855. Eugenia syzygioides (Miq.) M.R.Hend., Gard. Bull. Singapore 12: 154. 1949. Eugenia cymosa sensu Wight, Ill. 2: 17. 1841; Ic. 2: t. 555. 1843; Kurz, J. Asiat. Soc. Bengal 46(2): 67. 1877; Duthie in Hook.f., Fl. Brit. Ind. 2: 482. 1878; King, J. Asiat. Soc. Bengal 70(2): 100. 1901; Lectotype (designated by Byng et al., 2015): INDONESIA, "Java, in de wooden der westelijke streken", s.coll. s.n. (L [L0822705 digital image!]; isolecto L [L0822704 digital image!]).

Syzygium vimineum Wall ex P.H.Hô, Ill. Fl. Vietnam 2: 61. f. 3768. 1992.

Eugenia pseudosyzygioides M.R.Hend., Gard. Bull. Singapore 11: 315. 1947. 
Syzygium caudatum Wall., Numer. List no. 3591. 1831. nom. nud.

Eugenia viminea Wall., Numer. List no. 3593B. 1831. nom. nud.

Fig. 1

Large evergreen trees, to $20 \mathrm{~m}$ tall; old stems often buttressed at the base; bole straight; bark smooth, later becomes rough, slightly flaky, greyish-brown when mature; blaze ultimately turning reddishbrown; branches very slender, sub-terete and light green later become terete and pale greyish-brown, thickened at nodes; inter nodes 3-4 cm long. Leaves crimson-red when young; petioles slender, 0.5-1.5 cm long, slightly depressed above, black when dry; lamina elliptic-lanceolate to elliptic-oblong or ovate-elliptic, $6-9 \times 1.5-5.5 \mathrm{~cm}$, thinly coriaceous, pellucid punctate, cuneate at base, acuminate to caudate-acuminate at apex, acumen $0.5-1.5 \mathrm{~cm}$ long, slightly revolute along margins, greenish above, pale green beneath; midrib slender, slightly depressed above, raised beneath, black when dry; lateral nerves 35-42 per side, sub-parallel, narrowly spaced, 1-2 $\mathrm{mm}$ apart, indistinct above, distinct beneath; tertiaries faint, finely reticulate; intramarginal nerve 1-tiered, conspicuous, slender, c. $1 \mathrm{~mm}$ from margin. Inflorescence both terminal and axillary, 4-9 cm long, sub-corymbose panicles; flowers c. 38; peduncles $1.7-2.5 \mathrm{~cm}$ long, slender; peduncle and ramifications angled; ultimate branches end in 3 flowers. Bracts and bracteoles deltoid, c. $0.8 \times 0.3 \mathrm{~mm}$. Flowers sessile, $0.8-1 \mathrm{~cm}$ diam. at anthesis. Hypanthium campanulate, 3$3.5 \times 2.8-3 \mathrm{~mm}$, reddish outside. Calyx shallowly 4-lobed; lobes deltoid, reddish. Petals orbicular, $c$. $2 \mathrm{~mm}$ across, white with pinkish tinge, membranous, gland dotted, calyptrate. Stamens many, unequal, 3.5-5 mm long, white; anthers ovate; filaments filiform. Ovary 2-locular; ovules 19-22 per locule; style slender, c. $5 \mathrm{~mm}$ long; stigma simple, acute. Fruit globose to subglobose, 1.1-1.5 $\times 1.1-1.4 \mathrm{~cm}$, pericarp fleshy, green turns red to purple black when ripe, with smooth to undulating calyx rims, c. $1 \mathrm{~mm}$ high, 1-seeded.

Flowering \& fruiting: Flowering and fruiting from March to May.
Habitat: Syzygium syzygioides is found in the lowland mixed evergreen forests, at an elevation of $\pm 110 \mathrm{~m}$ above sea level and is associated with Syzygium mundagam (Bourd.) Chithra (Myrtaceae), Ixora brachiata Roxb. ex DC. (Rubiaceae), Artocarpus hirsutus Lam. (Moraceae), Lannea coromandelica (Houtt.) Merr. (Anacardiaceae), Macaranga peltata (Roxb.) Muell.-Arg. (Euphorbiaceae), Mallotus philippensis (Lam.) Muell.-Arg. (Euphorbiaceae), Calycopteris floribunda (Roxb.) Poiret (Combretaceae), Aporosa cardiosperma (Gaertn.) Merr. (Euphorbiaceae), Capparis fusifera Dunn (Capparidaceae), Mangifera indica L. (Anacardiaceae), Flacourtia montana Graham (Flacourtiaceae), Xanthophyllum arnottianum Wight (Xanthophyllaceae), Artabotrys hexapetalus (Linn.f.) Bhandari (Annonaceae), Salacia brunoniana Wight \& Arn. (Celastraceae), Terminalia paniculata Roth (Combretaceae), etc.

Distribution: Bangladesh, Cambodia, India, Laos, Malesia, Myanmar, Thailand and Vietnam.

Specimens examined: INDIA. Kerala, Kollam district, Arippa, \pm 110 m., 08.03.2019, S.M. Shareef 79283, 79284; Ibid.,16.03.2019, S.M. Shareef 79287, 79288; Ibid., 30.04.2019, S.M. Shareef 79292 (TBGT).

Notes: Syzygium syzygoides is an elegant tree which is more attractive during its flushing and flowering periods. It can be easily recognized from other species in the Western Ghats by the presence of slender and terete branchlets, crimson coloured young foliage, axillary and terminal inflorescences, small but white flowers with reddish tinged hypanthium and petals and small globose to subglobose fruits. The ripe fruits are edible (Deb, 1981), sweet but are not used by the inhabitants of the present locality. The author noticed that the seedlings of this species are collected by the forest nursery at Kulathupuzha, near Arippa and are planted in degraded forest areas of Kollam, Pathanamthitta and Thiruvananthapuram districts as part of afforestation programmes. They locally named it as 'Tholnjaval', but correct identity of the species was unknown to them. As part of ex-situ conservation, this species was successfully 


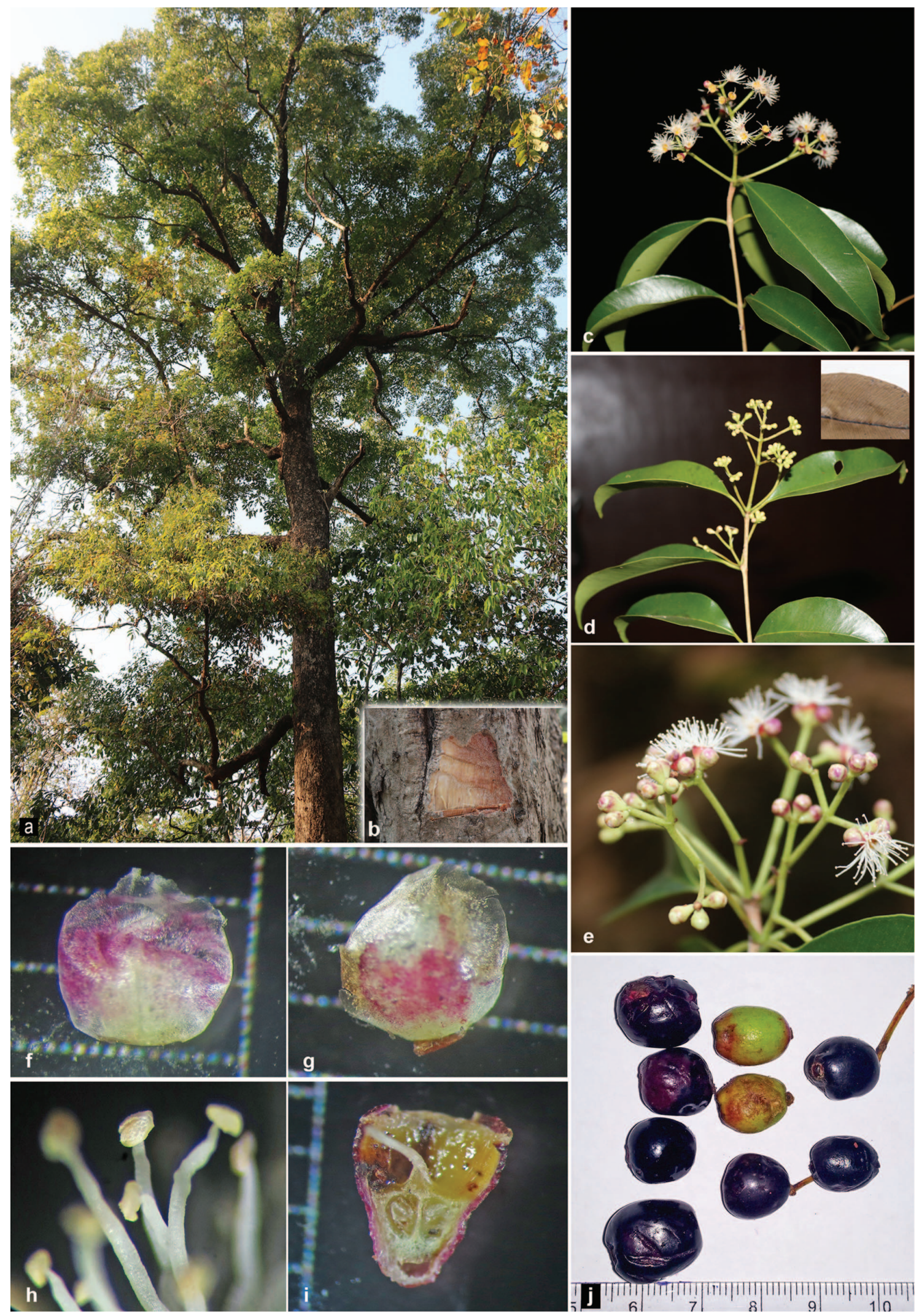

Fig. 1. Syzygium syzygioides (Miq.) Merr. \& L.M. Perry: a. Habit; b. Bark showing blaze; c-d. Flowering twig (inset: Leaf-under side); e. Inflorescence; f \& g. Petals; h. Stamens; i. L.S. of hypanthium showing ovary; j. Fruits (photos by S.M. Shareef). 
introduced in Jawaharlal Nehru Tropical Botanic Garden and Research Institute, Palode, Thiruvananthapuram.

\section{Acknowledgements}

The author is grateful to Wuu-Kuang Soh and John Parnell, Botany Department, School of Natural Sciences, Trinity College Dublin for confirming the identity of the species; the authorities of National Herbarium of the Netherlands (L) for providing the digital image of type specimens; the Director, JNTBGRI, Palode, Thiruvananthapuram for encouragement and facilities, and the forest officials of Kerala Forest Department for forest permission.

\section{Literature Cited}

BACKER C.A. \& R.C. BAKHUIZEN VAN DEN BRINK 1963. Flora of Java. Volume 1. Noordhoff, Netherlands. pp. 333-351.

BYNG J.W., WILSON P.G. \& N. SNOW 2015. Typifications and nomenclatural notes on Indian Myrtaceae. Phytotaxa 217 (2): 101-116. https://doi.org/ 10.11646/phytotaxa.217.2.1

DEB D.B. 1981. The flora of Tripura State. Volume 1. Today \& Tomorrow's Printers \& Publishers, New Delhi. pp. 366-373.

DUTHIE J.F. 1878. Order LIX. Myrtaceae, In: HOOKER J.D. (ed.), Flora of British India. Volume 2. L. Reeve \& Co., London. pp. 462-506.

GOVAERTS R., SOBRAL M., ASHTON P., BARRIE F., HOLST B.K., LANDRUM L.L., MATSUMOTO K., FERNANDA MAZINE F., NICLUGHADHA E., PROENCA C., SOARES-SILVA L.H., WILSON P.G. \& E. LUCAS 2020. World Checklist of Myrtaceae. Facilitated by the Royal Botanic Gardens, Kew. Available at: http://wcsp.science.kew.org(Accessed on 20.01.2020).

KANJILAL U.N., KANJILAL P.C. \& A. DAS 1938. In: KANJILAL U.N., KANJILAL P.C. \& A. DAS (eds.), Flora of Assam. Volume 2. Government of Assam, Shillong. pp. 257-287.

KURZ S. 1877. Forest flora of British Burma. Volume 1. Bishen Singh Mahendra Pal Singh, Dehra Dun. pp. 477-495.

MERRILL E.D. \& L.M. PERRY 1938. On the Indo-Chinese species of Syzygium Gaertner. Journal of Arnold
Arboretum 19: 99-116.

MIQUEL F.A.W. 1855. Flora van Nederlandsch Indië. Volume 1. Fleischer, Leipzig. p.431. https://doi.org/ 10.5962/bhl.title.93

MURUGAN C. \& S. ARUMAGAM 2017. Syzygium bournei (Myrtaceae) - A new species from the Western Ghats of Tamil Nadu, India. Indian Journal of Forestry 40(3): 281-283.

NARAYANAN M.K.R., SHAREEF S.M., SHAJU T., SIVU A.R., SUJANA K.A., NANDAKUMAR M.K. \& K.T. SATHEESH 2014. A new species of Syzygium (Myrtaceae) from the southern Western Ghats of Kerala, India. International Journal of Advanced Research 2(3): 1055-1058.

NAYAR T.S., BEEGAM A.R. \& M. SIBI 2014. Flowering plants of the Western Ghats, India. Volume 1. Dicots. Jawaharlal Nehru Tropical Botanical Garden and Research Institute, Thiruvananthapuram. pp. 19-934.

PARKINSON C.E. 1922. A forest flora of the Andaman Islands. Bishen Singh Mahendra Pal Singh, Dehra Dun. pp. 171-175.

PARNELL J.A.N., CRAVEN L. \& E. BIFFIN 2007. Matters of scale: dealing with one of the largest genera of angiosperms. In: HODKINSON T.R. \& J.A.N. PARNELL (eds.), Reconstructing the tree of life: Taxonomy and systematics of species rich taxa. Systematics Association, Taylor \& Francis, Boca Raton. pp. 251-273.

PARNELL J. \& P. CHANTARANOTHAI 2002. Myrtaceae. In: LARSEN K. \& T. SANTISUK (eds.), Flora of Thailand. Volume 7. The Forest Herbarium, Royal Forest Department, Bangkok. pp. 778-914.

RAMANA M.V., CHORGHE A. \& P. VENU 2014. Two new species of Syzygium (Myrtaceae) from Saddle Peak National Park, Andaman and Nicobar Islands, India. Blumea 59: 42-48. https://doi.org/10.3767/ 000651914 X683593

RAMASUBBU R., SURENDRAN A., DIVYA C., NAMBI S. \& M. GURUSWAMY 2018. A new species of Syzygium (Myrtaceae) from the South Western Ghats of Tamil Nadu, India. Phytotaxa 374(3): 263-267. https:// doi.org/10.11646/phytotaxa.374.3.8

RIDLEY H.N. 1922. The flora of the Malay Peninsula. Volume 1. L. Reeve \& Co. Ltd., London. p. 737.

SARMA J., BHARBHUIYA H. A. \& S. DEV 2019. A new Rheophytic species of Syzygium Gaertn. (Myrtaceae) from Assam, Northeast India. Adansonia 41(1): 53-58. https://doi.org/10.5252/adansonia2019v41a6

SHAREEF S.M., ROY P.E. \& M.V. KRISHNARAJ 2014. Syzygium munnarensis sp. nov. (Myrtaceae): an overlooked endemic species from southern Western 
Ghats of Kerala, India. Webbia 69: 53-57. https://doi.org/ 10.1080/00837792.2014.899727

SHAREEF S.M., SANTHOSH KUMAR E.S. \& T. SHAJU 2012. A new species of Syzygium (Myrtaceae) from the southern Western Ghats of Kerala, India. Phytotaxa 71: 28-33. https://doi.org/10.11646/phytotaxa.71.1.5

SOH W.K. \& J. PARNELL 2015. A revision of Syzygium Gaertn. (Myrtaceae) in Indochina (Cambodia, Laos and Vietnam). Adansonia 37(2): 179-275. http://dx.doi.org/ 10.5252/a2015n2a1

SUJANAPAL P., ROBI A.J. \& N. SASIDHARAN 2014. Syzygium sahyadricum (Myrtaceae), a new tree species from India, and notes on the distribution of $S$. spathulatum Thwaites. Phytotaxa 174(5): 285-290. https:/ /doi.org/10.11646/phytotaxa.174.5.5

SUJANAPAL P., ROBI A.J., UDAYAN P.S. \& K.J. DANTUS 2013. Syzygium sasidharanii sp. nov. (Myrtaceae) - A new species with edible fruits from Agasthyamala Hills of Western Ghats, India. International Journal of Advanced Research 1(5): 44-48.

VISWANATHAN M.B. \& U. MANIKANTAN 2008. A new species of Syzygium (Myrtaceae) from the Kalakkad-Mundanthurai Tiger Reserve in Peninsular India. Adansonia, Séries 3, 30(1): 113-118. 